\title{
Pædagogikken som hybrid mellem universitær dannelse og samfundsmæssig innovation
}

Helene Hagel, studerende, Institut for Statskundskab, Københavns Universitet.

Karen Lund Petersen, lektor, Institut for Statskundskab, Københavns Universitet.

Denne artikel zoomer ind på debatten om innovation ved kritisk at diskutere og undersøge, hvilke innovationsbegreber der optræder i den politologiske undervisning $i$ dag, og hvordan disse begreber om innovation $p a ̊$ hver sin måde definerer forholdet mellem universitet og samfund. Med udgangspunkt $i$ den forskningspolitiske debat om innovation og innovative kompetencer blandt universitetskandidater, diskuterer artiklen pædagogikkens rolle som 'fortolker' af forholdet mellem universitet og samfund. Vi argumenterer for, at der på Institut for Statskundskab, Københavns Universitet, opereres med to begreber om innovation: ét som betoner politikkens uforudsigelighed og ét, som i højere grad forholder sig til politik som en rumlig afgrænset sfære. Disse begreber beskriver, på hver sin måde, forholdet mellem universitetet og samfundet. Sidst diskuterer artiklen, hvordan forskellige laringsstrategier støtter disse forskelige begreber om innovation.

\section{Indledning ${ }^{1}$}

De politiske vinde taler for, at universitetskandidater i dag ikke alene skal vide noget om deres felt men i højere og højere grad også skal være kompetente entreprenører og innovatorer. Denne tendens ses tydeligt i forskningspolitikken, hvor der igennem forskellige strategiske satsninger lægges op til et øget samarbejde med det private erhvervsliv. Universitetet skal tænke sig selv i relation til samfundets behov og dermed bidrage til udvikling og vækst. Eller som uddannelsesminister Morten Østergaard (R) formulerer det $\mathrm{i}$ en tale om fremtidens akkrediteringssystem: "Uddannelsesinstitutionerne må finde sig $\mathrm{i}$, at samfundet trænger sig på. Og har forventninger

\footnotetext{
${ }^{1}$ Udgangspunktet for denne tekst er et projekt om innovative kompetencer gennemført på Institut for Statskundskab, KU, i 2013, finansieret af Copenhagen Innovation and Entrepreneurship Lab. I projektet har adjunkt Caroline Grøn, lektor Hanne Nexø Jensen, professor Peter Nedergaard og professor Mikkel Vedby Rasmussen deltaget. Herudover vil vi gerne takke Suzi Lyng Hansen, Janne Skakon og Trine Middelbo Sørensen for kommentarer til tidligere udkast.
} 
om uddannelse af højeste kvalitet og et 'afkast' som resultat af statens investeringer." ${ }^{2}$ Uddannelserne skal, som ministeren siger andetsteds, "styrke innovationskapaciteten i det danske samfund." ${ }^{3}$

Set med et undervisningspædagogisk blik kan uddannelsesministerens udtalelser læses som et opgør med den humboldtske dannelsestradition. ${ }^{4}$ Inden for denne tradition anses universitær dannelse og samfundsmæssig udvikling nemlig ikke som potentielt modsætningsfyldte. Som en professor i uddannelsespolitik skriver, bygger den humboldske tradition på idéen om en implicit social kontrakt mellem universitetet og samfundet og et meritokratisk ideal om at videnskabeligt dannede folk vil løse, eller som minimum bidrage til at løse, nationens store problemer (Enders, 2005, s. 123). Forholdet mellem universitet og samfund, mellem videnskabelig dannelse og samfundsmæssig udvikling, er således, indenfor den humboldske tradition, beskrevet som naturligt forenelig og harmonisk. Dette syn på læring og udvikling betyder desuden, at universitetspædagogikkens opgave både kan og skal defineres inden for rammerne af universitetet.

Dagens politiske diskurs er på mange måder et opgør med den humboldske fortolkning af relationen mellem universitet og samfund. Universitetets bidrag til samfundet er ikke naturligt givet, men samfundets behov og krav skal defineres og beskrives i den universitære praksis. I denne forstand er universitetspædagogikkens opgave blevet mere kompleks, da det langt hen ad vejen er her, at relationen mellem universitet og samfund fortolkes. Pædagogikken skal så at sige sikre, at universitetet bidrager til det omgivende samfund: at det nytter noget! I beskrivelsen af dette skift i universitetspædagogikkens rolle taler forskere ligefrem om et skifte fra den lukkede og elitære institution til det entreprenante universitet, som ser sig selv som en del af omverdenen (Blenker et al 2004). Målet for pædagogikken bliver i denne 'innovationsdiskurs', at genfortolke forholdet mellem universitær dannelse og samfundsmæssig innovation. Som Blenker et al. (2004) skriver, ligger der i denne vision for universiteterne "et nyt syn på læring, hvor det antages at entrepreneurielle kompetencer kan fremmes ved nye læringsformer" (s. 293). Undervisningsformer som casebaserede metoder, problemorientering, brug af spil og leg etc. handler således ikke kun om effektiv indlæring, men i lige så høj grad om hvordan vi forstår forholdet mellem

\footnotetext{
${ }^{2}$ Ministeriet for Forskning, Innovation og Uddannelse, Pressemeddelelse "Uddannelser skal give mening", d. 23/03 2012.

${ }^{3}$ Ministeriet for forskning, innovation og uddannelse: Pressemeddelelse Nye uddannelser skal imødekomme nye behov, den 15/5 2012. Europakommissionen har lignende visioner for universitetsuddannelserne i Europa, se rapporten Entrepreneurship in higher education, especially within non-business studies, European Commission, marts 2008.

${ }^{4}$ Wilhelm von Humboldt grundlagde Berlins universitet i 1810, og det humboldtske universitetsideal der her udvikledes, har været skabelonen for det moderne universitets udformning i den vestlige verden.
} 
universitær dannelse og de fremtidige samfundsmæssige behov (innovation). Valget af disse pædagogiske 'redskaber' beskriver en vision for, hvad samfundet er og bør være.

Denne artikel zoomer ind på debatten om innovation ved kritisk at diskutere og undersøge, hvilke innovationsbegreber der optræder i den politologiske undervisning i dag, og hvordan disse begreber om innovation på hver sin måde definerer forholdet mellem universitet og samfund. Ved at tage denne diskussion accepterer vi præmissen for dagens debat om innovation, nemlig at den humboldske model ikke alene kan beskrive nutidens universitetspædagogiske praksis, men at vi i vores daglige undervisningspraksis på forskellig vis fortolker relationen mellem universitær dannelse og samfundsmæssig innovation.

I det følgende vil artiklen først spørge til, hvordan man i undervisningen på Statskundskab, KU, fortolker sammenhængen mellem et politologiske dannelsesideal og samfundsmæssig innovation: Hvad er innovative kompetencer inden for politologien? Besvarelsen af dette spørgsmål er baseret på et projekt om innovative kompetencer i politologien, gennemført på Institut for Statskundskab, KU. I denne diskussion identificerer vi to begreber om innovation inden for politologien; begreber som udtrykker to forskellige fortolkninger af samfundsmæssig forandring (forudsigelighed versus usikkerhed). Efterfølgende specificerer artiklen, hvordan forskellige didaktiske greb understøtter disse begreber om innovation, og diskuterer hvilke visioner om samfundet, der ligger heri.

\section{Politologien som fagidentitet}

Hvad er sammenhængen mellem vores politologiske dannelsesideal og samfundsmæssig innovation? For at kunne svare på dette spørgsmål, er det nødvendigt at tage et skridt tilbage og spørge, hvad det politologisk dannelsesideal egentligt er (og bør være), og hvori relationen til innovation faktisk består?

Traditionelt har kurser i entrepreneurship og innovation været en del af fagudbuddet på handelshøjskolerne. Her har det centrale læringsmål været at lære kandidaten at se mulighederne for økonomisk gevinst/værdi (Schumpeter, 1934). Ideen om entrepreneurship var/er således historisk forbundet til ideer om resultatorienterede løsninger, økonomisk værdi og muligheden for styring mellem mål og midler. Der er åbenlyse problemer i blot at overføre den managementlogik til samfundsvidenskaberne. Og flere har derfor også peget på, at selve begrebet 'entrepreneurship' må udvides, hvis vi ønsker, at innovation skal række ud over individets evne til at nyttemaksimere (Gibb, 2002): Hvis vi ønsker at uddanne kandidater, som kan forstå, at samfundets behov - også i fremtiden - er mere end blot reguleret af 'den usynlige hånd'. 
Der er ingen tvivl om, at den økonomiske mål-middelrationalitet og det tilhørende fokus på management, kontrol og økonomisk vækst ikke 'bare' kan oversættes og implementeres i politologien. Helt åbenlyst ønsker vi at uddanne samfundsvidenskabelige kandidater, som også kritisk kan forholde sig til den generelle politiske udvikling; kandidater som kan vurdere de samfundsmæssige konsekvenser af forskellige løsningsmodeller, og som på denne baggrund kan identificere muligheder for forandring og udvikling.

I den forbindelse taler flere om 'social entrepreneurship'; et begreb som ofte modstilles med det økonomiske begreb. ${ }^{5}$ Argumentet er, at merværdi skal forstås i sin bredest mulige betydning og inkludere alt, lige fra den samfundsmæssige værdi til individuel selvrealisering. ${ }^{6}$ Merværdi er således ikke nødvendigvis knyttet specifikt til 'problemløsning' og 'individuel maksimering', men handler også om at se mulighederne i det bredere perspektiv: at udvikle narrativer, være kreativ og kunne skabe og udvikle ideer, i samarbejde og i dialog med andre.

\section{Koblinger mellem politologi og innovation}

De innovative kompetencer, som statskundskabsuddannelsen giver, er naturligvis tæt knyttet til både den viden og de(n) faglige identitet/færdigheder, som er forbundet med disciplinen politologi såvel som med den praksis, vi i dag forbinder med 'politik' (herunder bureaukrati).

Blandt et udvalg af forskere på Institut for Statskundskab, KU, blev det diskuteret, hvad innovation er inden for politologien, og i denne diskussion stod det klart, at vi på forskellig vis betoner begge former for temporalitet i begrebsliggørelsen af innovative kompetencer inden for politologien.

Figuren nedenfor ${ }^{7}$ er et forsøg på at konceptualisere, hvordan sammenhængen er mellem innovative kompetencer og de øvrige læringsmål, politologisk viden og færdigheder. Begrebet 'politisk katalysator' betegner den kandidat, som vi ønsker at uddanne, og som 'samler' den politologiske viden, færdigheder og kompetencer.

\footnotetext{
${ }^{5}$ Gregory Dees, Peter Economy and Jed Emerson: Enterprising nonprofits: A toolkit for social entrepreneurs, New York: John Wiley and Sons, 2001; Idee Winfield: "Fostering social entrepreneurship through liberal learning in the social sciences", Practice, 2005. Se også http://www.caseatduke.org/

${ }^{6}$ European Commission 2012: Entrepreneurship in higher education, s. 27.

${ }^{7}$ Figuren er inspireret af Tine Lynforts figur over forholdet mellem viden og innovative kompetencer inden for humaniora.
} 


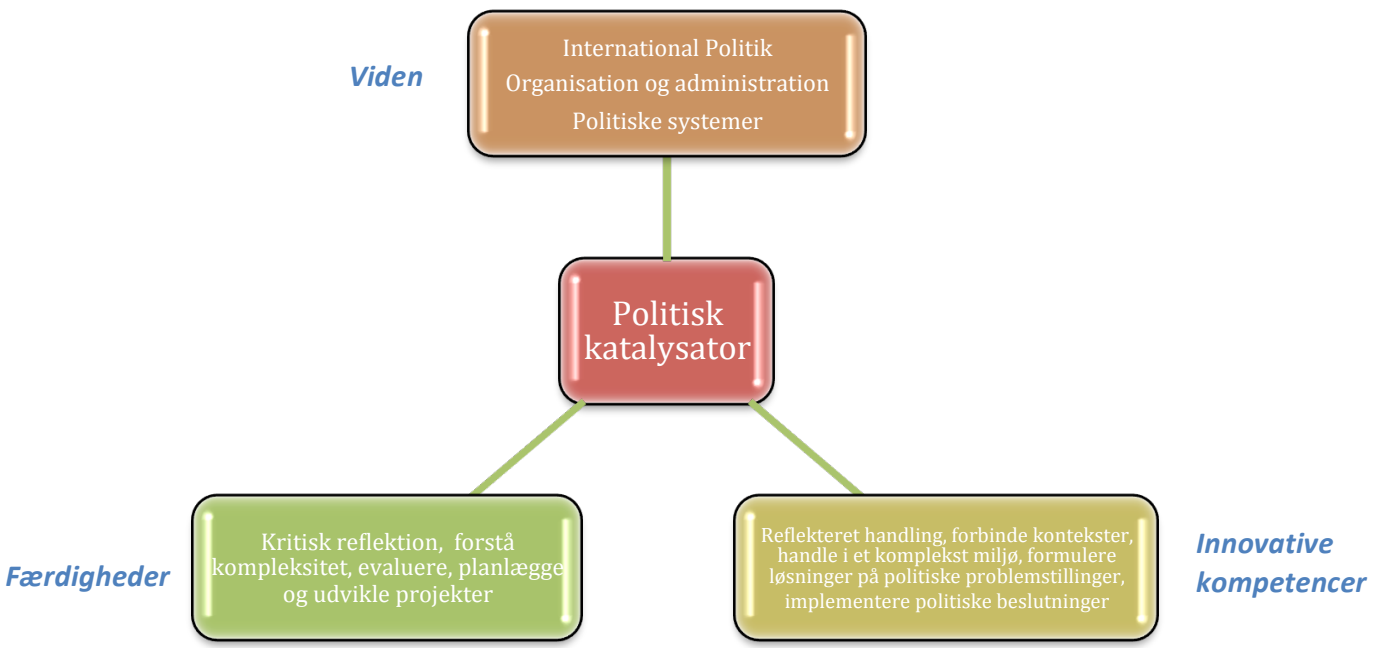

Figur 1: Sammenhængen mellem innovative kompetencer og de øvrige læringsmål, politologisk viden og færdigheder.

I diskussionerne stod det klart at 'den politiske beslutning' er central for formuleringen af 'politologiske innovative kompetencer'. Begrebet optræder dog i to betydninger. På den ene side er politiske beslutninger dem, som politologen skal kunne 'handle på' gennem planlægning, evaluering og implementering, og som forudsætter, at den politiske beslutning lokaliseres. På den anden side er den politiske beslutning også den, som 'producerer mening' og aktivt skaber nye muligheder (i medier, i private virksomheder, i sociale organisationer etc.). ${ }^{8}$ Her betones i særlig grad kompetencerne til at kunne identificere udviklinger og handle på nye muligheder i usikre omgivelser, hvorimod implementering, organisering og planlægning betoner evnen til at aktivere en række redskaber til at optimere løsningen af et defineret og lokaliserbart problem (erfaringer).

Således kobles det politologiske dannelsesbegreb til innovation på to måder, som hver især udtrykker en bestemt temporalitet: beskrivelse af relationen mellem fortid og fremtid. I sit studie af politiske begreber viser den tyske begrebshistoriker Reinhart Koselleck, hvordan alle politiske begreber refererer til to former for temporalitet, der tilsammen beskriver mulighedsbetingelserne for sociopolitisk handling. På den ene side har vi 'erfaringsrummet', som beskriver begrebets reference til fortiden, og

\footnotetext{
${ }^{8}$ Denne skelnen mellem politik forbundet med en rumlig afgrænset sfære og politik som aktivitet, der organiserer handling og producerer mening i relation til en forventet fremtid, er helt i overensstemmelse med de to politikbegreber, som Kari Palonen finder i sit studie af, hvordan termen 'politik' siden starten af 18-hundredetallet har været forstået. Palonen viser, at politik historisk har været forstået som mere end blot en sfære, et felt eller en 'disciplin'. Politik er, ifølge Palonen, også et 'handlingsbegreb' der beskriver mulighederne for nye udviklinger og alternative fremtider (Koselleck, 1985, s. 267; Nevers, 2007, s. 128).
} 
på den anden side 'forventningshorisonten', som beskriver visionen for fremtiden (Koselleck, 1985, s. 259). Denne distinktion mellem 'erfaringsrum' og 'forventningshorisont' er yderst relevant for at forstå de innovationsbegreber som der arbejdes med/tages i brug på statskundskab: ét begreb i højere grad betoner forudsigelighed (jf. erfaringer) og ét som betoner usikkerheder. Begge begreber handler om mulighederne for udvikling, værdiskabelse og vækst

Betegnelsen 'politisk katalysator' gør det muligt at forholde sig til begge forståelser af temporalitet og muliggør derved koblingen af innovation og politologi på to måder: Dels ved at se innovation som relateret til 'løsningen af bestemte opgaver'. Dette vil typisk være at give de studerende redskaber til at forbedre planlægningen, organiseringen og implementeringen af politiske og administrative beslutninger. Herudover handler innovation også om at skabe og 'identificere muligheder for samfundsmæssig forandring'; om at idéudvikle og definere nye strategier for handling. Samlet set handler innovation derfor både om evaluering, planlægning samt implementering og om refleksion, idéudvikling og samarbejde. Begge former for innovation åbner op for dialog mellem forudsigeligheds- og uforudsigelighedslogikkerne. Det innovative består således $\mathrm{i}$ at kunne navigere $\mathrm{i}$ disse forskellige typer af politiske beslutninger - at kunne trække på erfaringsrummet og benytte bestemte redskaber til at løse specifikke problemer, samt at kunne forholde sig aktivt til uforudsigelighed og se nye muligheder i et politisk miljø defineret af kompleksitet.

\section{Pædagogik og didaktik}

'Knowledge management' versus 'knowledge enabling'

Innovative kompetencer refererer således på forskellig vis til det kendte og det ukendte; evnen til at bruge den videnskabelige viden som er oparbejdet inden for disciplinen samt til, baseret på denne viden, at kunne idéudvikle, udnytte nye muligheder og skabe alternative fremtider.

For at integrere disse visioner i den undervisningspædagogiske praksis skelner man, inden for den pædagogiske forskning, mellem 'knowledge management' og 'knowledge enabling': mellem målstyring af vidensproduktionen og en muliggørelse af ny eller innovativ vidensdannelse (Gleerup, 2003, s. 33). 'Knowledge enabling' handler således om at kunne forholde sig til fremtidens udfordringer, mens 'knowledge management' på mere traditionel vis antager, at vi kan kontrollere processer, der i udgangspunktet er ukontrollerbare (Von Krogh et. Al., 2000, s. 4). Men hvordan finder man så den rette balance mellem 'knowledge management' og 'knowledge enabling'? Udfordringen, vi står overfor, er at bringe disse forskellige videns- og læringsformer i et aktivt og hensigtsmæssigt samspil; at sikre en praksis af pluralisme inden for forskellige vidensparadigmer, hvor logikken ikke er 'enten-eller', men snarere 'både-og'. 
Jørgen Gleerup giver et kvalificeret bud herpå ved at opstille tre vidensformer, som på hver sin måde supplerer og understøtter denne læring:

- Eksplicit viden er den traditionelle positivistiske viden. Rationalet er empiriske observationer og adskillelsen mellem subjekt og objekt. I pædagogisk praksis betyder dette, at undervisningen foregår med forventning om et bestemt resultat. Viden er her det, vi ved, at vi ved, og det, vi ved, at vi ikke ved. I innovationssammenhæng kunne dette være, at der på universitet udbydes kurser i statistisk metode, i projektstyring, eller kommunikation. Sådanne kurser vil typisk have til formål at formidle specifikke metoder til senere implementering i de organisationer, som de studerende skal arbejde $i$.

- Viden som proces er en hermeneutisk tilgang, hvor man således i den pædagogiske praksis anerkender, at det ikke er muligt at foretage en direkte overførsel af viden. Viden er det, vi ikke ved, at vi ved. Denne vidensform lægger op til, at den videnskabelige praksis etableres løbende og i alle fag. Casebaseret undervisning er et eksempel.

- Emergent viden er radikal ny viden, der opstår, når forskellige kulturer eller professioner aktivt interagerer. I et pædagogisk perspektiv anerkendes det, at hver profession/kultur/part kun ser et udsnit af virkeligheden. Ny viden opstår, når vi åbner op for det, vi ikke ved, at vi ikke ved. Nogle former for casebaseret undervisning vil kunne støtte en sådan vidensproduktion, såvel som rollespil, praktikforløb og simuleringer.

Når den viden, vi bestræber os på at aktivere hos de studerende, bliver mindre eksplicit og mindre baseret på erfaringer, vil vi flytte fokus til 'processen'. Det er i konceptualiseringen af viden som proces, at evnerne til at se nye muligheder etableres rækker ud i fremtiden og modellerer en forventningshorisont. Case- og praktikerinddragelse er blot nogle af de tiltag, der kan gøre op med ideen om udelukkende at formidle eksplicit viden i undervisningen, og i stedet qua forskellige former for samarbejdende praksislæring fokusere på mere aktiv og engagerende vidensformidling (Gleerup \& Wiedemann, 2003, s. 24).

Når vi gør op med det traditionelle videnshierarki (og dermed 'enten-eller'-logikken) vil det ændre den måde, vi tænker relationen mellem teori og praksis på, da inddragelsen af praksis skaber mulighed for at eksperimentere med forskellige synsvinkler og forståelsesformer. Når de studerendes - eksplicitte - viden konfronteres med andre professionsforståelser, vil denne viden netop blive tydelig (eksplicit), og det er i interaktionen mellem de studerende og praktikeren, at vi vil være i stand til at analysere og diskutere forskellige logikker og erkendelsesformer. Når praktikere inddrages i undervisningen, kan vi opnå en hermeneutisk sammensmeltning af horisonter og forankre vores forskning og undervisning i en kontekst, som lige såvel tilhører de 
studerende. Vi kan studere 'noget andet' end hvad, vi hidtil har beskæftiget os med, og den viden, "hvis synlige krop hverken er teoretisk eller videnskabelig diskurs eller litteratur, men en regelmæssig daglig praksis" ${ }^{\prime}$, er en essentiel universitær dyd, når "samfundet trænger sig på".

Casebaseret undervisning og spil som didaktiske greb til at fremme af forskellige læringsidealer

Brugen af cases anses ofte som afgørende for læring i samfundsvidenskaberne (Flyvbjerg, 2009, s. 86). Casestudier producerer en kontekstafhængig viden, som igennem forskning om læring har vist sig at være nødvendig for at lade studerende udvikle sig fra 'rule-based beginners' til 'virtuoso experts' (Flyvbjerg, 2009, s. 221). Målet er således at skabe en undervisningspraksis som ikke alene giver 'eksakt viden', men som støtter udviklingen af processuel og emergent viden. Spørgsmålet er dog stadig, hvordan sådan en viden og sådanne kompetencer bedst udvikles gennem casebaseret læring. Dette spørgsmål har vi i herværende artikel forsøgt at åbne op for. Men casebaseret undervisning er mange ting, og de mange former for casebasering støtter på forskellig vis de vidensformer, som Gleerup opstiller, og de innovationsbegreber, som der opereres med på Institut for Statskundskab.

Den traditionelle måde at benytte cases på i undervisningen stammer fra Harvard Business School (HBS), hvor den allerede i 1918 blev indført. ${ }^{10}$ Den betragtes i dag som en af grundene til skolens enorme succes (Mattison \& Ramberg, forthcoming), og kan anskues som det mest etablerede og institutionaliserede opgør med de klassiske humboldtske dannelsesidealer. Den case, som de studerende præsenteres for, er normalt skriftlig, men også multimedier og personlige præsentationer benyttes. Casen identificerer en situation og et specifikt problem fra den virkelige verden, som de studerende skal identificere, foretage en analyse af og derpå evaluere de forskellige handlemuligheder af. Denne metode er i høj grad blevet normen ift. hvad case-metodologien repræsenterer, når det kommer til formål, form og indhold (ibid., s. 1). Tanken er, at de studerende på HBS-uddannelsen har meldt sig til et 'bredt' program (en 'generalistuddannelse'; hvilket statskundskabsstudiet også er): Man uddanner altså generalister, der qua casebaseret undervisning skal have en 'basic management toolbox', og kunne benytte denne ift. at fremføre konkrete løsningsmodeller og anbefalinger. Der er i denne tradition en høj grad af studenteraktivitet, og underviserens rolle er primært at kanalisere energien til det rette sted og opsummere mere end at stimulere og iværksætte aktivitet (ibid.). Casen er altid eksemplarisk og genkendelig for de studerende; den indeholder en beskrivelsen af en faktisk situation, der invol-

\footnotetext{
${ }^{9}$ Som Foucault erfarede, da han tilbragte en stor del af sine dage i Paris i arkiverne på Bibliothèque National (Flyvbjerg, 2009,s. 157).

${ }^{10}$ Se Muckadell og Hvithamar (2013) for oversigt over forskellige casemetoder brugt indenfor humaniora.
} 
verer en beslutning eller udfordring for en person eller organisation. Her er besiddelsen af eksplicit viden og evnen til at implementere, analysere og trække på en erfaringshorisont således en nødvendighed. (Herskin, 2004; Mauffette-Leenders et al., 2001).

HBS's casemetode er som sagt den mest etablerede. Sammenlignet med de vidensformer, som Jørgen Gleerup opridser, er det dog primært 'eksplicit viden' og i nogen grad 'viden som proces', som understøttes af denne læringsform. Casemetoden er i høj grad baseret på at bekræfte en allerede eksisterende viden og målet er, gennem casearbejdet, at udvikle kompetencerne til at opstille generaliserbare løsnings- og beslutningsmodeller. Læring og viden er i denne sammenhæng tæt knyttet til erfaringer.

Lund University School of Economics and Managements (LUSEM) har udviklet en alternativ casemetode. I modsætning til det primære fokus på problemløsning og beslutningstagen, prioriterer denne model konceptuel tænkning (Gleerup \& Wiedemann, 2003, 3). LUSEM-metoden adskiller sig fra traditionel caseundervisning på følgende måder:

- Udvælgelse af cases. Ligesom i den mere traditionelle caseundervisning fokuserer man på en situation, hvor en beslutning er i fokus. Men de faktuelle omstændigheder er her ofte sværere at forstå og analysere, og de forskellige handlemuligheder er komplicerede og fordrer en del kritisk overvejelse. De studerende skal derfor selv undersøge feltet og give velbegrundede forslag til beslutningstageren. De skal bistå med den viden, der kan ligge til grund for beslutningen - uden nødvendigvis at anbefale en specifik beslutning.

- Spørgsmålene til de studerende er åbne og generelle. Fokus er på at træne evnen til at analysere situationen og benytte de bedst egnede analytiske redskaber til dette: Casen skal i højere grad evalueres og behandles analytisk end 'løses'.

- Underviseres rolle i casebaseret undervisning kan antage forskellige former: som en 'controller' er underviseren lederen og styrer derved diskussionen: de studerende reagerer på underviserens initiativer. Som 'facilitator' vil underviseren involvere de studerende i det givne felt men til stadighed fokusere på det emne og den dagsorden, underviseren selv har valgt. Underviseren bestemmer strukturen, hvori de studerende kan personalisere og internalisere koncepter. Endeligt kan underviseren fungere som en 'partner': her er underviserens primære rolle, at støtte den diskussion der finder sted internt blandt de studerende. LUSEM-metoden lægger vægt på at underviseren primært fungerer som en partner, der stimulerer de studerende individuelt og gør dem i stand til både at reflektere over og analysere cases. 
I LUSEM-metoden handler viden ikke blot om videreudvikling af eksisterende fagligheder, kvalifikationer eller kompetencer men om at skabe ny viden. Ny viden opstår med den innovative overskridelse af paradigmer og forforståelser og skal lokaliseres i de nye felter som manifester sig, når de indgår i et praksisfællesskab. Ingen af parterne kan, før mødet med 'den anden', gribe, omfatte eller på forhånd tage patent på denne ny viden, der kun vil være paradigmatisk ny, hvis den ikke konstrueres ud fra en given optik, men tværtimod opstår, når forskellige optikker mødes, overskrider eller transcenderer sig selv for at komme i kontakt med 'den anden' (viden) (Gleerup \& Wiedemann, 2003, s. 31). I denne casemetode er det 'viden som proces' og 'emergent viden', som prioriteres. Praktisk viden er således mere end blot en oversættelse af den teoretiske - og det er netop denne binære logik, dette traditionelle hierarki mellem disse to vidensformer, som denne undervisningsform forsøger at gøre op med.

En sådan form for casebaseret undervisning er dog ikke den eneste form, der kan fremme 'emergent viden'. Et andet eksempel er pædagogiske redskaber baseret på leg. Leg er, som Niels Åkerstrøm Andersen påpeger i sin bog om emnet, en ekstrem form for 'supervision af selvstyring'. Leg handler om at "eksperimentere med mulige realiteter, adfærd og identiteter" (Mainemelis \& Ronson, citeret i Åkerstrøm Andersen, 2008). Supervision bliver at 'lege med det at lege'. Man skal ikke lære noget bestemt, men man skal lære at være lærende. Der er således tale om en ikke-lineær form for læring, en konceptualisering af pædagogik, hvor det drejer sig om at 'lære at lære'. Åkerstrøm Andersen skelner i den forbindelse mellem 'træningslege' og 'skabelseslege' som pædagogiske kommunikationsformer. I træningslege eller spil er et eksplicit og ofte præcist læringsformål defineret; det handler om at træne bestemte kompetencer i relation til en beslutning. Simulationsspil inden for fx efterretningsstudier er et godt eksempel på en sådan træningsleg. I et sådant spil er reglerne givet, og selve formålet med spillet klart beskrevet.

I skabelseslege har legen derimod værdi i sig selv, og ikke kun i relation til dets umiddelbare funktion og formål:

"Det pædagogiske blik på skabelseslegene ser ikke legen som en pædagogisk teknik til at lære noget bestemt $i$ forhold til at udfylde en professionsbaseret rolle. (...) Set fra pædagogikkens blik drejer disse lege sig ikke om at lære en given fxrdighed eller kompetence, men om at se sig selv som kompetence" (Åkerstrøm Andersen, 2008, s. 182).

Man skal anlægge et pædagogisk blik på sig selv og sine perspektiver på verden, for dermed at blive både strateg for personlig selvudvikling og et kompetencemål i sig selv (ibid., s. 183). Forventningen om fremtiden er således helt grundlæggende for 
denne læringsform, som kun på et meget subtilt niveau forholder sig til allerede etableret viden og erfaringer. At være kompetent bliver nu at kompetenceudvikle sig selv, hvilket kræver, at man ser sig selv som ufærdig.

\section{Konklusion}

Denne artikel var et forsøg på at vise, hvordan pædagogikken og forskellige didaktiske begreb fortolker relationen mellem 'det vi kan' (nemlig producere viden) og det vi anser som samfundets behov (samfundsmæssig innovation).

Artiklen viste, at der på universitetet findes mange fortolkninger af dette forhold, der på forskellig vis betoner en erfaringsbaseret viden versus evnen til at skabe nye fremtider og muligheder. På Institut for Statskundskab, KU, kan man (som minimum) tale om to begreber om innovation: Et der forholder sig til politik, som knyttet til et bestemt disciplinært læringsrum, og som primært handler om den studerendes evne til at overføre eksisterende viden til fremtidig praksis; en anden fortolkning handler om den studerendes evne til at 'stå på kanten' af den eksisterende (erfaringsbaserede) viden og kunne formulere nye muligheder for praksis. Ingen af de to begreber er ekskluderende men udtrykker forskellige lærings- og vidensidealer.

Forskellige former for undervisningspraksis støtter disse innovationsbegreber og vidensidealer. Casebaseret undervisning kan, som nævnt, både støtte, hvad Jørgen Gleerup kalder en 'eksakt viden' og dermed et innovationsbegreb, der betoner det at overføre erfaringsbaseret viden til brug i en fremtidig praksis. Andre undervisningsmetoder støtter mere emergente vidensidealer og sætter derved fokus på selvstyring og evnen til at lære at lære.

Vi har i denne artikel forsøgt at åbne op for en idé om, at pædagogikken ikke er en autonom størrelse, men skal være kvalificerende for en bestemt aktivitetstype, der handler om nyskabelse og forandring. Vores fokus på innovation i undervisningen skal således ikke læses som en accept af uddannelsesministerens konceptualisering af begrebet, men snarere som en nødvendig supplement til de klassiske humboldtske dannelsesidealer; et fokus, der betoner nødvendigheden af at tænke kritisk om den praksis og kompetenceudvikling, som refereres til i innovationens navn.

Vi har bestræbt os på at kritisere den hegemoniske politiske diskurs ved at vise, hvor essentielt det er at anerkende nødvendigheden af at uddanne kandidater, der kan tænke fremtiden ind i nutiden - både den fremtid, der kan skabes ved at trække på allerede-etableret viden og erfaringer, men i højere grad også den alternative fremtid, der kan udvikles af kritisk tænkende, reflekterende og innovative kandidater. 
Ligesom uddannelsesminister Morten Østergaard er vi dog heller ikke parate til at smide det klassiske universitets dyder over bord. Som han formulerede det ved Forskningspolitisk Årsmøde tidligere i år: "Universitetet i dag skal kunne rumme både dybde og bredde. Dannelse og konkrete kompetencer. Fordybelse og erhvervsrettethed. Og både fortid og nutid." ${ }^{11}$ Problemet er bare, at han glemte fremtiden.

Helene Hagel har i 2013 været forskningsassistent på et projekt om innovative kompetencer på Institut for Statskundskab, KU, i samarbejde med Copenhagen Innovation and Entrepreneurship Lab (CIEL). Derudover har hun arbejdet som studenterassistent på Centre for Advanced Security Theory (CAST), på Dagbladet Politiken, i DR Byen og senest i FN's Klimasekretariat (UNFCCC). For tiden skriver hun speciale om klimaforandringer, ekspertise og innovation ved Institut for Statskundskab, KU.

Karen Lund Petersen er lektor ved Institut for Statskundskab, Københavns Universitet, samt studieleder for den engelsksprogede kandidatuddannelse i Security Risk Management. I 2013 stod hun i spidsen for et CIEL-finansieret projekt om udviklingen af innovative kompetencer blandt studerende på Statskundskab. Til dagligt forsker Karen i sikkerhedspolitik og risikostyring og er leder af forskningscenteret Centre for Advanced Security Theory.

\section{Litteratur}

Adler, E. \& Pouliot, V. (red.) (2011). International Practices. Cambridge Studies in International Relations 119. Kapitel 1, 1-36. Cambridge: Cambridge University Press.

Blenker, P., Dreisler, P., Færgemann, H. \& Kjeldsen, J. (2004). Uddannelse og Entrepreneurship - et signalement af universiteternes nye rolle? Ledelse E Erhvervsøkonomi 4 (2004), 293-302.

Christensen, A.W., Krab, J. \& Sander, E.(2006). Viden og vilje i pædagogers arbejde. (Antologi). København: BUPL.

Dees, G., Economy P. \& Emerson, J. (2001). Enterprising nonprofits: A toolkit for social entrepreneurs. New York: John Wiley and Sons.

Enders, J. (2005). Border crossings: Research training, knowledge dissemination and the transformation of academic work, Higher Education, 49(2), 119-133.

European Commission (2008). Entrepreneurship in higher education. Hentet fra: http://ec.europa.eu/enterprise/policies/sme/promoting-entrepreneurship/ education-training-entrepreneurship/higher-education/index_en.htm

Flyvbjerg, B. (2009). Samfundsvidenskab som virker. Hvorfor samfundsforskningen fejler, og hoordan man fär den til at lykkes igen. København: Akademisk Forlag.

Gibb, A. (2002). Creating conducive environments for learning and entrepreneurship; living with, dealing with, creating and enjoying uncertainty and complexity. Industry and Higher Education, 1(3).

\footnotetext{
${ }^{11}$ Uddannelsesminister Morten Østergaards tale ved Forskningspolitisk Årsmøde, Videnskabernes Selskab, den 12/03 2013.
} 
Gleerup, J. \& Wiedemann, F. (2003). Pædagogisk Forskning og Udvikling. Odense: Syddansk Universitetsforlag.

Gleerup, J. (2004). Teori om forskellige vidensformer: Viden(skabs)teori. In: B. Hansen \& J. Gleerup (red.): Vidensteori, professionsuddannelse og professionsforskning. Odense: Syddansk Universitetsforlag.

Jørgensen, H. T. (2009). Didaktisk kreativitet. En undersøgelse af hvad vi kan forstå ved didaktisk kreativitet, og hvordan og hvornår det kan opstå. Århus: VIA University College, Læreruddannelsen i Århus.

Kasza, G. J. (2006). Unearthing the roots of hard science: A program for graduate students. In: S. F. Schram \& B. Caterino (Eds.), Making Political Science Matter. Debating Knowledge, Research and Method. New York: New York University Press.

Koselleck, R. (1985). Futures past: On the semantics of historical time. New York: Columbia University Press.

Krain, M. (2010). The effects of different types of case learning on student engagement. International Studies Perspectives, 11(3), 291-308.

Mauffette-Leenders, L. A., Erskine, J. A. \& Leenders, M. R. (2001). Learning with cases. Ontario: Ivey Publishing.

Mattison, O. \& Ramberg, U. (forthcoming). The LUSEM Case method - an alternative approach? - Some reflections on hands-on learning and abstract thinking.

Ministeriet for Forskning, Innovation og Uddannelse (2012). Pressemeddelelse: $U d$ dannelser skal give mening, d. 23/03 2012.

Ministeriet for forskning, innovation og uddannelse (2012). Pressemeddelelse: Nye uddannelser skal imødekomme nye behov, den 15/5 2012.

Muckadell, S. \& Hvithamar, A. (2013). Case-baseret undervisning - et overset værktøj for klassiske humanistiske fag. Dansk Universitetspædagogisk Tidsskrift, 7(13), 41-50.

Nevers, J. (2007). Spørgsmålets politik: Kari Palonen og den nyere begrebshistorie. Slagmark 48, 123-37.

Ramian, K. (2012). Casestudiet i praksis. (2. udgave). København: Hans Reitzels Forlag.

Schram, S. F. \& Caterino, B. (red.) (2006). Making political science matter. Debating knowledge, research and method. New York: New York University Press.

Schumpeter, J. A. (1934). The theory of economic development. Cambridge: Harvard University Press.

Van Wynsberghe, R. \& Khan, S. (2007). Redefining case study. International Journal of Qualitative Methods, 6(2).

Winfield, I. (2005). Fostering social entrepreneurship through liberal learning in the social sciences. Practice 7(3), 15-17.

Zoltan J. A. \& Szerb, L. (2007). Entrepreneurship, Economic Growth and Public Policy. Small Business Economics, 28(2-3), 109-122.

Åkerstrøm Andersen, N. (2008). Legende magt. København: Hans Reitzel Forlag.

Åkerstrøm Andersen, N. \& Sand, I.-J. (red.) (2012). Hybrid forms of governance. Selfsuspension of power. Basingstoke: Palgrave. 